\title{
ABBASÎ HALÎFESİ VE FRENK HÜKÜMDARI BÜYÜK KARL İLİŞKİSİ
}

\author{
Nadir KARAKUŞ*
}

\begin{abstract}
Özet:
IX. yüzyılın hemen başlarında Abbasi İmparatorluğu Doğu'nun en parlak ülkesidir. Aynı zamanda Batı'da da hayranlıkla izlenmektedir. Abbasi halifesi Harûn Reşid, daha şehzade iken İmparatoriçe İrene'yi itaat altına alarak cizye vermeye mahkûm etmişti. Halife olduktan sonra da, Bizans İmparatoru Nikeforos itaate yanaşmayınca, Konya Ereğli'ye kadar gelerek İmparatordan bağlıık yemini almış ve cizye miktarını artırarak ona boyun eğdirmişti. Bizans ile güç mücadelesi içindeki Batı'daki güçlü Charlemagne de Harûn'u hayranlıkla izlemektedir. Charlemagne'nin komşusu Endülüs ise, Harûn ile mücadele içindedir. Endülüs Müslümanları da Franklar karşısında bu sıralarda Pireneler'de durdurulmuşlardır. Ortak menfaatler Charlemagne ile Harûn'u birbirlerine yaklaştıır. Karşılıklı elçi alışverişinde bulunulur. Kudüs'e gidecek hacıların güvenliği ve karşılıklı işbirliği öngörülmektedir. Elçilik heyetlerinin gönderilmesi yanında iki Hükümdar'ın birbirlerine hediyeler göndermeleri ve bu hediyelerin mahiyeti ile ilgili masalımsı ve efsanevî detaylar, bu ilişkiyi gölgede bırakarak, tarihi bir olayı adeta magazinleştirir. Doğu'nun zenginlikleri ve refahı Batı'da farklı algılarla abartıır, "Bin Bir Gece Masalları"nın da etkisiyle gerçekleri gölgede bırakır. Oldukça abartılan bu hediye edilen nesneler, mahiyeti aydınlatılması gereken elzem bir mesele haline geldiği için böyle bir araştırmaya intiyaç duyulmuş ve gerçekler tarihî olaylar ışığında açığa çıkarılmaya çalışılmıştır.
\end{abstract}

Anahtar kelimeler: Harûn, Charlemagne, Bağdat, İstanbul, Kurtuba, Aix, Hediye

\section{The Relationship Abbasid's Caliphate And Great Karl Who The King Of Franks}

\begin{abstract}
:
The Abbasid Empire is the most radiant country of the East, in the early years of the ninth century. At the same time it is viewed with admiration in the West. The Abbasid caliphate Harûn al-Rashid, subordinated empress Irene under his rule and sentenced her to pay Jjzya (Tax) when he was an heir to the throne.After becoming caliphate, when the Byzantium emperor Nikhephoros refused to obey, he came as far as Konya Ereğli and forced him into submission by receiving his oath of allegiance and raised the amount of jizyaln the West which was in a power struggle with the Byzantium, the mighty Charlemagne was also watching Harûn with admiration. Whereas, Charlemagne's neigbour Al-Andalus was in conflict with Harûn. In this period, Andalusian Muslims were stopped at the Pyrenees by the Franks. Common interests brought Charlemagne and Harûn closer. They exchanged ambassadors. Mutual collaboration was foreseen by ensuring the safety of the pilgrims travelling to Jerusalem. In addition to the exchange of ambassador delegations, the exchange of gifts between the two rulers and the legendary and fairy tale details of the contents of these gifts have shadowed the actual relationship and has transformed this historic event into a tabloid issue. The wealth and riches of the East is exaggerated in the West with different perceptions and the truth is swept aside with the effect of "One Thousand and One Nights Stories". There was a need for this research in order to shed light on to reality in terms of historical events because the issue of clarifying the contents of the much exaggerated objects which have been given as a gift became essential.
\end{abstract}

Key Words: Harûn, Charlemagne, Baghdad, Istanbul, Cordoba, Aix, Gift

\footnotetext{
Yrd. Doç. Dr., Hitit Üniversitesi İlahiyat Fakültesi, nadirkarakus@hitit.edu.tr
} 


\section{Giriş}

VIII. yüzyılın sonları ve IX. yüzyılın hemen başlarında, üç önemli şehir dünyanın parlayan yıldızlarıydı. Bunlar İber yarımadasında müreffeh bir devlet kurmuş olan genç Endülüs Emevîleri'nin başkenti Kurtuba ${ }^{1}$, diğeri ondan çok uzaklarda, insanlığın ilk yerleşim yerlerinden biri kabul edilen bir bölgede, Dicle nehrinin her iki yakasına kurulan görkemli ve parıltılı şehir Bağdat ${ }^{2}$, üçüncüsü de pek çok sarsıntı geçirmesine rağmen, daha önce Romalılar'a da başkentlik yapmasının kadîm izlerini taşıyan Kostantinopolis. ${ }^{3}$

Kendisinden önce aynı topraklar üzerinde kurulmuş olan Ur, Bâbil ve Ktesifon gibi başşehirleri çoktan geride bırakan ${ }^{4}$ Bağdat, bir taraftan düşman gördüğü Bizans ile ezelî kavgalarını verip, onu mağlup etmeye devam ederken, diğer yandan da rakibi olarak gördüğü, kendisinden çok uzaklardaki Kurtuba'yı takip etmekteydi. Bizans, Bağdat karşısında geri adım atarken, Balkanlar'da da yeni güç kaybına uğramakta, yerini Avrupa'nın yeni efendisi Frenk hükümdarı Charlemagne'ye kaptırmakta idi. Frenkler ise, bir yandan da sınırlarının diğer ucundaki Kurtuba'ya karşı Pireneler'in kendi toprakları tarafındaki bölümünde parlak zaferler kazanmakta idiler. ${ }^{5}$ Rakibi konumundaki Bizans'1 alt etmesine rağmen, endişeli Frenkler, dikkatlerini Bizans'a karşı can yeleği olarak gördükleri Bağdat'a yönelterek, onlarla ittifak arayışı içine girmeye çalışıyorlardı. Rakibi Kurtuba'dan Frenkler vasıtası ile emin olabileceğini ümit eden Bağdat da bu yakınlaşmaya sıcak bakmak zorundadır. Tarihî olaylar, bazı fantezilerle süslenmekte, efsane ve hikâyelerle ilginç hale getirilmektedir. Doğu'nun zenginliğine hayran Batılı tarihçiler için bol bol malzeme çıkabilecek, hikâyeler uydurulabilecek bir ortam doğmuş gibi idi.

AbbasîHalifesi Harûn er-Reşîd'in "Doğu Roma" diye adlandırabileceğimiz Bizansla olan münasebetleri, hem doğu hem de batı kaynaklarında oldukça nettir. Onun Fransa ile ve kudretli hükümdarı Büyük Karl (Charlemagne) ile olan dostane münasebetlerinden de bahsedilir ki, aynı netlik ve teferruat

1 bk. J. Wasserstein, The Caliphate in the West, Oxford 1993, s. 34-39.

2 İbn Battûta, Tuhfetü'n-Nüzzâr fì Garâibi'l-Emsâr ve Acâibi'l-Esfâr, neş.: Ali el-Muntasır, Beyrut $1981-85$, c. I, s. $140-41$.

3 Theophanes Continuatus, Chronographia, Corpus Scriptorum Historiae Byzantinae, Bonn 1838, s. 420 .

4 P. K. Hitti, Siyâsî ve Kültürel İslâm Tarihi, çev.: Salih Tŭ̆, Boğaziçi Yayınları, İstanbul 1980, c. II, s. 468.

5 Mehmet Özdemir, “Endülüs”, Dİ, İstanbul 1995, c. XI, s. 213. 
bu ilişkilerde yoktur. Her ne kadar Harûn er-Reşîd Çin gibi uzak ülkelere tafsilatı anlatılmayan diplomatik ilişkiler kursa da, ${ }^{6}$ Fransa ile coğrafî uzaklık ve sınır farklılıkları dolayısıyla, sıcak bir ilişkinin kurulmasının pek de kolay olmayacağı bir gerçektir.

Biz bu makalemizde, özellikle Frenk-Abbasî ilişkileri, dolayısıyla Charlemagne-Harûn ilişkisinden ve bu ilişkinin gerçek olup olmadığından bahsedeceğiz. Bu bölgelerin, dokuzuncu yüzyılın hemen başında içinde bulundukları tarihî, sosyal, kültürel; hatta ekonomik durumu Harûn er-Reşîd ve Charlemagne' nin kişiliklerinde ortaya koymanın, bahsedilen ikili ilişkilerin daha iyi değerlendirilip, anlaşılmasında büyük bir yarar sağlayacağına inaniyoruz.

\section{Harûn er-Reşîd}

Harûn er-Reşîd (786-809), Halife Muhammed Mehdî’nin Oğlu ve BeŞinci Abbasî Halifesi'dir. ${ }^{8}$ Ünü "Bin Bir Gece Masalları" ${ }^{9}$ ile doğu ve batıya yayılan Harûn $^{10}$, bu sıralarda döneminin en kudretli hükümdarıdır.

Daha şehzadeliği esnasında gaza için Bizans'a gitmiş ve İmparatoriçe İrene ile her yıl 70.000 dinar göndermesi şartı ile sulh akdetmişti. ${ }^{11} 163$ /77980 yılında babasının emri ile Bizans hududundaki Semâlu halkını muhasara ederek, başarılı bir sefer gerçekleştirdi. ${ }^{12}$ İkinci seferi 165/781-82 yıllarında

6 Usamuddin Abdurrauf el-Fakî, ed-Devletü'l-Abbasiyye, Kahire 1987, s. 65-6. Çin'e ilk dönemlerden itibaren Müslüman tüccarların gittiği unutulmamalıdır. bk. Gülçin Candarlıŏlu, “Çin”, DIA, İstanbul 1993, c. VIII, s. 321-22; İslâm coğrafyacısı İbn Hurdazbih, Çin'e giden yoları tüm teferruatı ile anlatmaya çalışmıştır. bk. İbn Hurdazbih, el-Mesâlik ve'l-Memâlik, neş.: M. J. De Goeje, Leiden 1967, s. 69; Çin'de İslâmiyet için ayrıca bk. İbn Battûta, Tuhfetü'n-Nüzzâr, c. II, s. 717-736.

7 Harûn'un, Mehdî’nin üçüncü oğlu olduğu belirtilir. bk. F. Omar, "Harûn al-Rashid", $E I^{2}$, c. III, s. 232.

8 K. V. Zettersteen, "Harûnurreşid", İA, İstanbul 1977, c. V/1, s. 304.

9 bk. Veli Ulutürk, "Binbir Gece" DIA, c. VI, s. 180; E. Littmann, "Alf layla wa layla”, $E I^{2}$, c. I, s. 358-364.

10 K. V. Zettersteen, "Harûnurreşid", İA, c. V/1, s. 304.

11 Hayreddin ez-Ziriklî, Kamusu'l-A'lâm, (Kamus-u Terâcim), Beyrut 1980, c. VIII, s. 62.

12 Belâzürî, Futuhu'l-Buldan, çev.: Mustafa Fayda, Siyer Yayınları, Ankara 1986, s. 197. 
oldu. Thrakesion Theması ${ }^{13}$ içinde yapılan savaşı kazanarak $^{14}$ İstanbul boğazının doğu yakasındaki Khalkedon'a (Kadıköy) kadar giderek Bizanslılar ile sulh anlaşması imzaladı. Bu sefer İrene'nin her yıl ödeyeceği haraç miktarı 90.000 dinara çıkmıştı. ${ }^{15} \mathrm{Bu}$ başarıları üzerine babası Mehdî tarafından "erReşîd" ünvanı ile onurlandırıldı. ${ }^{16}$

Şevval 186/Ekim 802'de İrene'nin tahttan indirilmesi ${ }^{17}$ üzerine iktidara gelen onun maliye vekili Nikephoros ${ }^{18}$, daha önce imzalanan anlaşma şartlarını reddetti. ${ }^{19}$ Harûn Nikephoros'a karşı iki kez sefere çıkarak ona boyun eğdirdi ve son seferinde (190/806), Konya Ereğli'sine (Heraklea) kadar ilerleyerek, burayı fethetti; Tyana (Niğde) bölgesini de işgal ederek, birçok sınır kalesini ele geçirdi. ${ }^{20}$ İmparatoru yeni bir vergi vermeye, buna ilave olarak da, şahsı ve ailesi için de bir nevi baş vergisi vermeye mecbur bıraktı. ${ }^{21}$

Yine her yaz Bizans'a karşı seferler düzenletti. ${ }^{22}$ Bizans'a karşı ayrıca sınır boylarında Avasım ve Suğurlar ${ }^{23}$ oluşturdu. ${ }^{24}$ Mansur devrinden itibaren çok büyüyen Cünd-i Kinnesrîn'i, merkezi Menbic ${ }^{25}$ olmak üzere Avâsım adıyla

13 Sardes'ten Efes'e giden yolun birleştiği noktada Alaman Boğazı'nın ilk girişinde yükselen tepe üzerinde "Keçi Kalesi" olarak da bilinen Bizans kalesidir. bk. Emine Tok, "Aşağ1 Kaystros Vadisinde Türkmen Akınlarına Karşı Bir Sığınak: Keçi Kalesi”, Sanat Tarihi Dergisi, XXV/2, Ekim 2016, s. 249-275.

14 Işın Demirkent, “Bizans”, DİA, İstanbul 1992, c. VI, s. 235.

15 Işın Demirkent, "Bizans", DİA, İstanbul 1992, c. VI, s. 235.

16 Nahide Bozkurt, "Hârûnürreşîd", DİA, İstanbul 1997, c. XVI, 258-261.

17 Georg Ostrogorsky, Bizans Devleti Tarihi, çev.: Fikret Işıltan, Türk Tarih Kurumu Yayınları, Ankara 1981, s. 192.

18 Işın Demirkent, “İstanbul”, DİA, İstanbul 2001, c. XXIII, s. 205-212.

19 İbn'ul-Esir, el-Kâmil fi't-Tarih, Misır, 1301, c. VI, s. 78; Muhammed el-Hudari, Tarihu'lÜmemi'l-İslâmiyye, (ed-Devletü'l-Abbasiyye), Misır 1970, c. I, s. 130.

20 Işın Demirkent, "Bizans", DİA, İstanbul 1992, c. VI, s. 235.

21 İbnu'l-Esir, VI,78; Hitti, History of the Arabs, New York 1968, s. 300; İbn Kesir, el-Bidaye ve'nNihâye, Beyrut 1966, c. X, s. 203.

22 Ebû Cafer Muhammed b. Cerir et-Taberî, Tarihu'r-Rusül ve'l-Mülûk, tahk.: Muhammed Ebu'l-Fadl İbrahim, Kahire 1968-69, c. VIII, s. 234, 236, 239, 241.

23 İslâm devletlerinin gayrı müslim devletlerle sınır teşkil eden müstahkem şehir ve kalelerin bulunduğu uç bölgeleridir. bk. Abdurrahman M. Abdülganî, el-Hudûdü'l-Bizantiyye elİslâmiyye ve Tanzîmâtüha's-Sagriyye (40-339/660-950), Küveyt 1410/1990.

24 Belâzürî, 188; Corci Zeydan, İslâm Medeniyeti Tarihi, çev.: M. Çelik, İletişim Yayınları, İstanbul 1976, c. I, s. 273; Mustafa Zeki Terzi, Emeviler ve Abbasiler Zamaninda Malatya Hudut Garnizonu, 19 Mayıs ÜIF Dergisi, Samsun 1989, say1: 3, c. III, s. 115.

25 Mukaddesî, Ahsenü't-Tekâsim, çev.: D. Ahsen Batur, Selenge Yayınları, İstanbul 2015, s. 82'de Menbic'i dördüncü iklim kuşağında Mezopotamya yakınında bir yer olarak zikreder. 
müstakil bir bölge haline getirdi. ${ }^{26} \mathrm{Bu}$ yeni eyalet Antakya'dan güneybatıda Âsî nehrinin denize döküldüğü yere, güneydoğuda Halep, Menbic ve bunun kuzeyinde Bizans sınırına kadar uzanan araziyi içine alıyordu. ${ }^{27}$ Daha özel bir hat ile burası Menbic, Dülûk, Ra'bân, Kûrus, Antakya ve Tîzîn'in birleştirilmesinden oluşan bir bölge idi. ${ }^{28}$ Harûn, ayrıca bu müstahkem mevkilere askerler yerleştirmiştir. ${ }^{29}$ Harûn, Menbic' deki görevlisi Muhammed b. İbrahim'e mektup yazarak, el-Hades şehrini tamir ettirerek ${ }^{30}$ buraların imarına özel bir önem verdiğini göstermiştir. Yine 173/ 789 yılında Menbic'e Abdülmelik b. Salih'i göndererek, ona bazı binalar yaptırmıştır. ${ }^{31}$ 171/787 yılında Harûn'un emri ile Bizans seferine çıan Abbasîler'in önde gelen kumandan ve valilerinden Horasanl ${ }^{32}$ Herseme b. A'yen, aynı zamanda Tarsus'un tahkimi ile de görevlendirilmişti. Daha sonra buralara çeşitli bölgelerden askerî birlikler getirilip yerleştirilmiştir. ${ }^{33}$ 172/ 788 yılında Tarsus'a bir cami ve kale de inşa edilmişti. ${ }^{34}$

Yine Harûn zamanında Kıbrıs'a karşı Humeyd b. Ma'yuf adlı komutanı vasıtasıyla başarılı bir sefer düzenlendi. ${ }^{35}$ Onları itaat altına alarak, pek çok da esir aldı. ${ }^{36}$ Yine aynı komutanın önderliğinde Girit adası fethedildi. ${ }^{37}$

Harûn, İmar faaliyetlerine de önem verdi ve geride pek çok eser biraktı. $\mathrm{Bu}$ dönemde Bağdat, Dicle nehrinin iki yakasına kurulmuş pek çok saray ve köşklerle, dünyanın en güzel şehirlerinden biri haline gelmişti. ${ }^{38}$ Harûn zamanında rüya şehrin doğu tarafı, Şemmâsiyye Kapısı'ndan Muharrim'e

26 E. Honigmann, Bizans Devleti'nin Doğu Sinırı, çev.: Fikret Işıltan, IÜ Edebiyat Fakültesi Yayınları, İstanbul 1970, s. 36 vd.

27 H. Dursun Yıldız, “Avâsım”, DİA, İstanbul 1991, c. IV, s. 111.

28 Belâzürî, s. 154-55.

29 Taberî, c. VII, s. 234.

30 Belâzürî, s. 222.

31 Belâzürî, s. 155.

32 Nahide Bozkurt, "Herseme b. A'yen", DİA, İstanbul 1998, c. XVII, s. 258-261.

33 Casim Avcı, "Suğur", DIA, c. XXXVII, s. 473-74; Herseme'nin aynı zamanda Filistin topraklarının işletilmesi için de gönderildiği rivayet edilir, bk. Belâzürî, s. 168.

34 Belâzürî, s. 196.

35 Belâzürî, s. 180; komutanın adı Ma'yuf b. Yahya olarak zikredilir ve 190/806 tarihi verilir, bk. İbn Kesir, c. X, s. 203.

36 Belâzürî, s. 180.

37 Belâzürî, s. 270; Girit yerine İkrîdış kaydı verilir. Ancak adanın tamamıyle fethi, Halife Me'mun döneminde (813-833) Ebû Hafs Ömer b. İsâ el-Endelüsî tarafından gerçekleştirilmiştir, Cemal Tukin, "Girit", DİA, İstanbul 1996, c. XIV, s. 85.

Nahide Bozkurt, “Hârûnürreşîd”, DİA, İstanbul 1997, c. XVI, s. 258-261. 
kadar genişledi. Eşi Zübeyde Hanım, biri Dicle kenarında, hilâfet saraylarına yakın bir yerde, diğeri şehrin kuzeyindeki Katîa' da olmak üzere iki muhteşem cami yaptırdığı gibi Huld sarayı yakınlarında da Karâr adlı bir köşk inşa ettirdi. ${ }^{39}$

183/ 799 yılında kendi adına yaptırdığı Harûniyye şehri yeni bir yerleşim olarak önemli bir boşluğu doldurdu. ${ }^{40}$ Endülüslü seyyah İbn Cübeyr ${ }^{41}$ Harûn'un Cidde şehrinde yaptırdığı iki abanoz direkli bir mescitten bahseder. Yine Şam bölgesinde Lukam dağının batı vadilerinden birinde Harûn tarafından yaptırılan Harûniye adlı küçük kale İslâm coğrafyacılarının ilgisini çekmiştir. $^{42}$ İmparatorlukta mamur şehirler ve müreffeh bir hayat vardır. O'nun zamanında dünyanın denge merkezi olarak kabul edilen Basra'da ${ }^{43}$ her tarafa bolluk ve bereket saçan 4.000 kanaldan bahsedilir. ${ }^{44}$ Oğlu Mehdî’ yi 165/781-2 yılında Bizans üzerine gönderdiğinde, Mehdî, el-Massîsa ve camiini tamir ettirmişti. Yine $\mathrm{O}$, Seyhan üzerindeki Ezene köprüsü kenarında bir de köşk yaptırmıştı. ${ }^{45}$

Harûn er-Reşîd, Hz. Ömer'in emriyle Amr b. el-Âs'ın valiliği döneminde yeniden onarılarak VIII. yüzyıla kadar kullanılan, ${ }^{46}$ Akdeniz ile Kızıldeniz arasındaki ulaşımı kolaylaştırmak ${ }^{47}$ ve Kızıldeniz'de ticarî faaliyeti çoğaltmak için ${ }^{48}$ bugünkü Süveyş kanalı projesini geliştirmiş, fakat böylesi bir projenin Bizans saldırılarını kolaylaştıracağı düşüncesiyle sonra bu niyetinden vazgeçmiştir.

Ailesi de bu görkemli ve göz kamaştırıcı günlerin önemli aktörleridir. Eşi ve amcasının kızı ${ }^{49}$ Zübeyde Hanım'ın Bağdat'tan Mekke'ye kadar,

39 Abdülaziz ed-Dûrî, "Bağdat", DİA. Ayrıca bk. G. Le Strange, Baghdad During the Abbasid Caliphate, Oxford 1924; Mahmud Şükrî el-Alûsî, Tarîhu Mesâcidi Bă̆dâd ve Asâruhâ, Bağdat 1346.

40 Belâzürî, s. 198.

41 İbn Cübeyr, Endülüs'ten Kutsal Topraklara, çev.: İsmail Güler, Selenge Yayınları, İstanbul 2003, s. 46.

42 İbn Havkal, 10. Asırda İslâm Coğrafyası, çev.: Ramazan Şeşen, Yeditepe Yayınları, İstanbul 2014, s. 159.

43 Mukaddesî, s. 116.

44 İbn Havkal, s. 196.

45 Belâzürî, s. 195.

46 Mustafa L. Bilge, "Süveyş", DİA, İstanbul 2010, c. XXXVIII, s. 186-187.

47 İ. Süreyya Sırma, Abbasiler Dönemi, Beyan Yayınları, İstanbul 1990, s. 63-64.

48 W. Barthold, F. Köprülü, İslâm Medeniyeti Tarihi, Akçağ Yayınları, Ankara 1984, 229.

49 Cafer b. Ebû Cafer el-Mansur'un kızıdır, İbn Cübeyr, s. 152. 
havuzlar, göletler, kuyular ve menziller yaptırdığı, ${ }^{50}$ Dicle kıyısındaki meşhur Maşuk Kalesi'nin yakınındaki mesire yerinin de O'na ait olduğu zikredilir. ${ }^{51}$ Yine Zübeyde Hanım, Akdeniz kıyısında Tarsus şehrine yakın Suğûr yolu üzerindeki Bağras adlı müstahkem kalede bir Daruzziyâfe inşa ettirmişti. ${ }^{52}$ Zübeyde Hanım, ayakkabılarını mücevherat ile süslemesi ile de yeni bir çı̆̆ır açmışt1. ${ }^{53}$

Sarayı âlimlerin ve sanatkârların buluşma yeri olmuşs, ${ }^{54}$ edip ve şairler hürmet görmüştü. Meşhur dilbilimci ve nahivcilerden Ebû Ubeyde Mamer b. Müsennâ, davet edilerek Basra'dan, "Medinetü's-Selâm" diye ma'ruf Bağdat'a ${ }^{55}$ davet edilmiş, 200 kadar eser bırakmıştır. Harûn'un Abbasî Halifeleri'nden en son hacca gelen kimse olduğu ve o zaman pek çok kalabalığın toplandığı rivayet edilir. ${ }^{56}$ Ebû Hanife'nin önde gelen öğrencisi, müçtehit hukukçu ve ilk Kâdılkudât'lardan Ebû Yusuf Yakup b. İbrahim (ö.182/798), meşhur eseri Kitabu'l-Harâc' 1 Harûn'a takdim etmiş ${ }^{57}$, mukaddimesinde de Harûn'a nasihatlerde bulunmuştur. ${ }^{58}$

Kitaba ve öğrenmeye o kadar değer vermiştir ki, Beytülhikme' nin ${ }^{59}$ zenginleşmesi için büyük çaba harcamış ve bazen cizye olarak kitap almıştır. ${ }^{60}$ Özellikle Ankara ve Ammûriye'nin fethinden sonra, buralardan elde edilen kitaplar Bağdat'a götürüldü ve Yuhannâ b. Mâseveyh başkanlığındaki bir heyet tarafından Arapça'ya tercüme edildi. Ayrıca İranlı bir mühtedi olan Ebû Sehl el-Fazl b. Nevbaht da Harûn' un emriyle Farsça' dan çeviriler yapıyordu. ${ }^{61}$ Bir başka yetenekli kişi Allân el-Verrâk eş-Şuubî ise Harûn için kitap istinsah ediyordu. ${ }^{62}$ Çeviri yapanlarda biri de, Öklid'in "Elementler"ini, Harûn için

\footnotetext{
50 İbn Cübeyr, s. 152.

51 İbn Cübeyr, s. 169.

52 İbn Havkal, s. 161.

53 Hitti, c. II, s. 534.

54 Belâzürî, s. 556.

55 Mukaddesî, s. 122.

56 İbn Cübeyr, s. 124.

57 Salim Öğüt, “Ebû Yusuf”, DİA, İstanbul 1994, c. X, s. 261-264.

58 Ebû Yusuf, Kitâbü'l-Harâc, neş.: Muhibbüddin el-Hatîb, Kahire 1382, s. 3-4.

59 Ortaçağ İslâm ilim ve kültür tarihinde tercüme ve yüksek seviyedeki ilmî araştırmaların yapıldığ1 merkezlere verilen ad. Diğer ismi, "Hizânetü'l-Hikme"'dir. Ahmed Emin, Duha'l-İslâm, Beyrut 1933-36, c. II, s. 64-65.

60 Hizır Ahmed Atâullah, Beytü'l-Hikme fi Asri'l-Abbasiyyîn, Kahire ts. s. 30.

61 Mahmut Kaya, "Beytülhikme”, DİA, İstanbul 1992, c. VI, s. 89.

62 Nahide Bozkurt, "Hârûnürreşîd", DIA, İstanbul 1997, c. XVI, s. 239.
} 
"Usulü'l-Hendese" adıyla Arapça'ya tercüme eden Haccâc b. Yusuf b. Matâr idi. ${ }^{63}$ Döneminde Bağdat'ta bir kâğıt fabrikasının kurulması ${ }^{64}$ Abbasîlerin yaşadıkları çağdaki ilmî ve kültürel seviyeyi çok iyi anlatır.

Musikî konusunda da Abbasîler Döneminin zirvesi bu dönemde yaşanmış, İbrahim ve oğlu İshak el-Mevsılî́م ${ }^{65}$ gibi musikişinaslar önemli çı̆̆ırlar açmışlardır. ${ }^{66}$ Bir kıskançlık sonucu Bağdat'tan kaçarak, Kurtuba'ya kaçan, İbrahim el-Mevsılî’' nin ${ }^{67}$ ve oğlu İshak'ın öğrencisi olan musikişinas Ziryâb (ö.238 / 852) da döneminin önemli sanatçlarından birisi olarak, doğuda ve batıda isminden bahsettirmiştir. ${ }^{68}$ Bir başka müzisyen olan Muhârık'1n, Dicle üzerinde bir gece gezintiye çıktığında söylemeye başladığı şarkının halk üzerinde bıraktığı derin etki hep anlatılır. ${ }^{69}$

$\mathrm{Bu}$ dönemde Bağdat'ta Cündişâpûr'daki ${ }^{70}$ gibi bir de hastane kurulmuştur. ${ }^{71}$ Harûn bu hastahaneyi, Cibrâîl b. Buhtîşû' b. Curcîs'i bizzat Bağdat'a çağırarak, Kerhâyâ Kanalı kenarında kurdurmuş ve başına da ünlü hekim Ebû Yuhannâ Mâseveyh'i geçirmişti. ${ }^{72}$

63 Ali b. Yûsuf el-Kıftî, Kitâbu İhbâru'l-Ulemâ bi Ahbâri'l-Hukemâ, Kahire 1326, s. 46. Bu eseri önce Harûn, sonra da Me'mun için olmak üzere iki defa tercüme etmiş, birincisine "elHarûnı̂", ikincisine ise "el-Me'mûn̂̀" denilmiştir.

64 M. Hanefi Palabıyık, "Müslümanlarda Kitap Kültürü ve Kütüphaneler", İslâm Kurumları Tarihi, edit.: Eyüp Baş, Grafiker Yayınları, 1. Baskı, Ankara 2013, s. 481.

65 bk. J. W. Fück, "Ishak b. Ibrahim al-Mawsilı””, EI², c. IV, s. 110-111.

66 P. K. Hitti, Siyasî ve Kültürel İslâm Tarihi, çev.: Salih Tŭ̆, Boğaziçi Yayınları, İstanbul 1995, c. II, s. 651. Fuat Sezgin, İslâm'da Bilim ve Teknik, çev.: Abdurrahman Aliy, Türkiye Bilimler Akademisi Yayınları, Ankara 2007, c. I, s. 24'de, Musikî konusunda, Ebu'l-Ferec Ahmed b. Hüseyin el-İsfehânînnin "Kitabu'l-Eganî" sinin Harûn'un direktifleriyle, üç meşhur müzisyen tarafından bir araya getirildiğini, daha sonra büyük müzisyen ve edebiyatçi; aynı zamanda da iyi bir ûdî olan İshak b. İbrahim el-Mevsılî (150-235/767-850) tarafından düzenlenerek, genişletildiğini zikreder. Ancak Ebu'l-Ferec'in 356/969 yılında öldügünü düşünürsek bu bilginin yanlış olduğunu görürüz.

67 Arap musikisinde klasik ekolün önemli temsilcilerindendir. 900'ün üzerinde eser bestelemiş, kendi icadı olan mâhûrî usulünü çok iyi kullanmıştır. Arap eğitim tarihinde sadece kadınlardan oluşan ilk düzenli musiki okulunun kurucusudur. Samha Amin alKholy, The Function of Music in Islamic Culture, Cairo 1984, s. 85.

68 Hitti, c. II, s. 651; Fazlı Arslan-Fatih Erkoçoğlu, "Ziryâb”, DİA, İstanbul 2013, c. XLII, s. 464.

69 Muhârık'ın, Harûn'dan 100.000 dinar mükâfat aldığı söylenir. bk. Hitti, c. II, s. 653.

70 İran'1n Hûzistan bölgesinde Sâsânî hükümdarlarından I. Şâpûr b. Erdeşîr (241-273) tarafından kurulan Kâzerûn yakınlarında Sûs ile Hemedan şehirlerini birbirine bağlayan yol üzerinde kurulmuş bir bilim, tıp ve sanat merkezidir. bk. Recep Uslu, "Cündişâpûr", DIA, İstanbul 1993, c. VIII, s. 117.

71 Nahide Bozkurt, "Hârûnürreşîd", DIA, İstanbul 1997, c. XVI, s. 258-261.

72 Arslan Terzioğlu, "Bîmâristan”, DİA, İstanbul 1992, c. VI, s. 164. 
Harûn er-Reşîd'in kişiliği Bizans'ta övgü ile konuşulur olmuştur. G. Ostrogorsky, Bizans İmparatoru Theophilos' u şöyle anlatır:

“...Adaleti ile meşhur Halife Harûn'u taklit ederek, tebdili kıyafetle şehirde dolaşır, tebaasının en fakir, en güçsüzleri ile konuşur, bunların şikâyetlerini dinleyerek, suçluları makam ve mevkilerine bakmayarak, ibret alacak şekilde cezalandırırdı." 73

Kısaca Harûn'un her konuda yeteneğini, idarî ve askerî dehâsını, döneminin kültürel ve ilmî gelişimini, Abbasîlerin her konudaki gelişim ve kalkınmışlığını özetlemeye çalıştığımız bu bölümün, makalemizin merkezinde niçin Harûn er-Reşid'in olduğunu açık ve net olarak anlatacağını ümit ediyoruz.

\section{Charlemagne}

Bu sırada, Frenk Devletinin başında ortaçağın en büyük hükümdarlarından biri olan Charlemagne bulunuyordu. 768-814 yılları arasında günümüz Fransa'sının büyük bir kesimini, Almanya, İtalya, Belçika, Lüksemburg ve Hollanda'yı kapsayan geniş bir bölgeyi egemenliğine alarak, uzun süreden beri kullanılmayan Batı İmparatoru unvanını almaya hak kazand1. ${ }^{74}$ "Carolus Magnus" ve "Charles The Great" olarak da Batı'da büyük bir itibar kazandı. Kendisiyle birlikte danışmanı Turpin de Batı' da bilge bir kişi olarak tanındı. ${ }^{75}$

Bavyera' $y^{76}$ ilhak ederek, Sakslar'1 Hıristiyanlaştırıp devletine katmış, doğuda Slav ülkelerine yönelerek, Avar Devletini ortadan kaldırmıştı. ${ }^{77}$

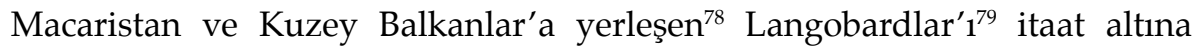
almasıyla da, devletini zamanındaki en kudretli Hiristiyan ülkesi haline getirmişti. ${ }^{80}$

73 G. Ostrogorsky, s. 193.

74 Thomas Asbridge, Haçlı Seferleri, çev.: Ekin Duru, Say Yayınları 1. Baskı, İstanbul 2014, s. 28.

75 Harold Lamb, Selahaddin Eyyubi ve Haçlılar, çev.: Sinem Ceviz, İlgi Kültür Sanat Yayınları, 1. Bask1, İstanbul 2017, s. 145.

76 Merkezi Münih olan Almanya'nın, yüzölçümü bakımından en büyük eyaletidir.

77 Fransa, V. Yüzyılın ortalarında Atilla kumandasındaki Hun ordusunun akınlarına uğramıştı. Yaklaşık 250 yıl sonra Charlemagne, Avarlar'ı yenerek bunun acısını da çıkartmış oluyordu. bk. Azmi Özcan, "Fransa", DİA, İstanbul 1996, c. XIII, s. 178.

78 Kemal H. Karpat, "Balkanlar", DIA, İstanbul 1992, c. V, s. 28.

79 Kavimler Göçü ile Doğu Avrupa'da yerleşmiş Avarlar'a verilen addır.

80 Vladimir Potyemkin ve diğerleri, Uluslararası İlişkiler Tarihi, çev.: Atilla Tokatlı, Evrensel Basım yayın, İstanbul 2009, c. I, s. 75; G. Ostrogorky, s. 170. 
Charlemagne kendisini dini savunma ve sürdürme hakkına sahip kutsal bir hükümdar ilan etti. ${ }^{81}$ Bugün Güney Fransa'da, Marsilya'nın 30 km. kuzeyinde bir şehir olan başkenti Aix ${ }^{82}$, başta Danimarka ve İngiltere olmak üzere birçok Avrupa ülkesinden akın eden elçilik heyetleri ile dolup taşıordu. Kendisine Avusturya Kralı II. Alphonso ve İskoç Kralları da onur elçileri yollamışlardı. Bu sıralarda bütün Avrupa Charlemagne ile dostluk ilişkileri kurma peşinde idi. ${ }^{83}$ Langobardları mağlup etmek suretiyle $\mathrm{O}$, Bizans'ın bir türlü başa çıkamadığı ve bu sebeple Roma'daki bütün itibar ve nüfuzunu kaybettiği bir görevi başarı ile yerine getirmişti. Bundan sonra Roma kilisesi, Franklar Devleti ile bağlarını daha da sıkılaştırmış ve Bizans'tan da yüz çevirmişti. ${ }^{84}$ Papa Charlemagne'ye İmparatorluk tacını büyük bir gururla, bizzat kendisi giydirmişti. ${ }^{85}$ Böylece papalık, Büyük Karl'ın himayesine girmiş oluyordu. ${ }^{86}$ Hatta Papa tarafından O'na, "Yeni Costantinus" ismi verilerek bizzat taltif edilmiştir. ${ }^{87}$

Charlemagne, ayrıca kendisini İslâm ülkelerindeki,özellikle deKudüs'teki Hristiyanların hamisi olarak görüyordu.$^{88}$ Daha imparatorluk tacını giydiği yıl, Kudüs Piskoposu O'na özel bir elçi yollamış ve İsa'nın mezarının anahtarıyla birlikte, kutsal kentin bayraklarını da teslim etmişti. ${ }^{89}$ Charlemagne de, Harûn ile kurduğu dostluk sayesinde hac için Kudüs'e gelenlerin kalacakları yerler yaptırmış ve bir adet de kütüphane oluşturmuştu. ${ }^{90}$

\section{İlişkilerin Başlaması ve Ortak Menfaatler}

Doğunun ve batının bu iki kudretli hükümdarının karşılıklı olarak birbirlerine elçilik heyetleri gönderdiklerinden bahsedilir. ${ }^{91}$ Birbirlerinden oldukça uzak

\footnotetext{
81 T. Asbridge, s. 30.

82 Charlemagne' den yaklaşık 4 asır sonra V. Haçlı Seferi için yola çıkacak olan Fransa Kralı VI. Henry'nin oğlu Frederic Hohenstaufen, taç giyme töreninden sonra, Aix -1- Chapelle'deki Charlemagne mağarasındaki kutsal haçı alarak sefere çıkmıştı. bk. Lamb, s. 320.

83 V. Potyemkin, c. I, s. 75.

84 G. Ostrogorsky, s. 170.

85 V. Potyemkin, c. I, s. 76.

86 Işın Demirkent, “Bizans", DIAA, İstanbul 1992, c. VI, s. 235.

87 V. Potyemkin, c. I, s. 76.

88 Muhammed Hudari, c. I, s. 133.

89 V. Potyemkin, c. I, s. 76.

90 Casim Avc1, "Kudüs", DİA, İstanbul 2002, c. XXVI, s. 327-329.

91 Ziriklî, A'lâm, c. VIII, s. 62; Rıza Kurtuluş, "Avrupa”, DİA, c. IV, s. 52-3; Zettersteen, "Harûnurreşid", İA, c. İstanbul 1992, İstanbul 1991, V/1, s. 304-305.
} 
olan bu iki kudretli hükümdarı birbirine yakınlaştıran sebep ise oldukça açıktır: Karşılıklı olarak birbirlerinden menfaatlerinin olması. Charlemagne, Harûn'u kendi düşmanı olan Bizans'a karşı muhtemel bir müttefik olarak görüyor, Harûn'da O'nu İspanya'da kudretli ve müreffeh bir devlet kurmaya muvaffak olan Endülüs Emevîleri'ne karşı kullanmak istiyordu. ${ }^{92}$

Her iki lider de İspanya'daki Endülüs'lü yöneticilere iyi duygular beslemiyorlardı. ${ }^{93}$ Endülüs'teki valiler döneminde Abdülaziz b. Mûsâ'nın Teodomiro'yu (Mürsiye) hâkimiyeti altına alışından sonra valilerin birçoğu, bütün gayretlerini Pireneler'i aşarak Frank topraklarında yayılmak için sarf ettiler. Bu gayretler sonunda İslâm orduları Fransa'nın güneyindeki Septimania ve Narbona bölgelerini ele geçirerek, bugünkü Paris'in bulunduğu bölgeye yaklaştılar. Ancak Müslümanlar Tours ve Poitiers şehirleri arasında yer alan ovada Franklar'a yenildiler. İslâm Tarihi'nde "Balâtüşşühedâ" adıyla geçen bu savaş onların kuzeye doğru ilerlemesini durdurmuştu. ${ }^{94}$ Fransa'nın en kültürlü ve bereketli bölgelerinden biri olan Akitanya ${ }^{95}$, Charlemagne zamanında İspanya'da Müslümanlara karşı verdiği kutsal savaş ile ünlenmişti. ${ }^{96} \mathrm{Bu}$ sırada Endülüs'te I. Hakem (796-822) yönetimin başında idi. Dönemi iç karışıklıklarla geçtiği için, bu durumdan faydalanan Franklar, 185/ 801 yılında Berşelûne'yi işgal ettiler. ${ }^{97} 193 / 809^{\prime}$ da Turtûşe' yi de istilâ etmek isteseler de başarılı olamamışlardı. ${ }^{98}$

Bu sırada Kurtuba da o dönemin bir başka cazibe merkezi, kültür, sanat ve ilim başkenti idi. ${ }^{99}$ İslâmî Dönemde çağdaşı İstanbul ve Bağdat kadar kozmopolit ve renkli idi. Pazarlarında dünyanın her yerinden gelen, her zevke uygun mallar sergileniyordu. Kurtuba, Avrupa'da, cadde aydınlatmasina sahip ve hamamları olan ilk şehirdi. 600 cami ve medrese, 800 hamam, 50 hastane ve çeşitli sanayi tesisleri vardı. Âlimlerin ve sanatkârların yetiştiği bir yer olduğu kadar Asya, Avrupa ve Afrika'dan ilim adamlarını kendine

92 Hitti, s. 298; Muhammed Hudari, c. I, s. 133.

93 L. V. Vaglieri, "Abbasî Hilâfeti", İslâm Tarihi Kültür ve Medeniyeti, çev.: H. Aktaş, İstanbul 1988, c. I, s. 128 .

94 Thomas Asbridge, Haçlı Seferleri, çev.: Ekin Duru, Say Yayınları, İstanbul 2014, s. 41; Mehmet Özdemir, "Endülüs", DIA, İstanbul 1995, c. XI, s. 213.

95 III. Haçlı seferlerinin önemli aktörlerinden annesi Fransız olan İngiltere Kralı Arslan Yürekli Richard, doğum yeri olarak buraya izafe edilir. bk. Asbridge, s. 382.

96 Asbridge, s. 382.

97 Mehmet Özdemir, “Endülüs”, DIA, İstanbul 1995, c. XI, s. 213.

98 Mehmet Özdemir, "Hakem I", DIA, İstanbul 1997, c. XV, s. 173.

99 bk. P. K. Hitti, Capital Cities of Arab Islam, Minneapolis 1973, s. 135-163. 
çekmesi ile de ünlü idi. ${ }^{100}$ Kurtuba'dan Bağdat'a gidenler, Kurtuba'nın Bağdat'ın iki yakasından biri gibi olduğunu söylerlerdi. ${ }^{101}$ Damları kiremit kaplı olan evleri ve güzel manzarası da seyyahların dikkatini çekmişti. ${ }^{102}$

Kurtuba cephesinde bunlar olurken Bizans İmparatoru Nikeforos, Charlemagne'nin imparatorluk ünvanını reddederek, gücünü görmezden geliyordu. Bunda, Kudüs'ün savunmasının O'na değil de, Charlemagne'ye verilmiş olmasının ${ }^{103}$ önemli bir yeri olduğu düşünülebilir. Aslında Charlemagne'nin Bizans'tan çekinmesi Nikeforos'tan öncesine dayanıyordu. Bizans ile yakınlaşmak için İmparatoriçe İrene ile evliliği dahi düşünmüş, ama İrene tahttan indirilince bundan vazgeçmiştir. ${ }^{104}$

Harûn'un Bizans ile olan ilişkilerini ve mücadelesini ise, yukarıda vermeye çalıştık. Bütün bu aktarmaya çalıştığımız bilgiler ışığında, Bağdat'ın dillere destan halifesi Harûn ile Batının kudretli Kralı Charlemagne'nin bu dostane münasebetleri niçin kurduklarını ve onları birbirlerine yaklaştıran nedenlerin neler olduğunu daha iyi anlarız.

$\mathrm{Bu}$ ilişkilerin gerçekleştirildiği yıllar ise, 181-191/797-806'dır. ${ }^{105}$ Uzak mesafeler arasındaki bu sıcak diyalog, elçiler heyetlerinin gönderilmesi ile başlamıştır. ${ }^{106}$ İlk sefaret heyetini Bağdat'a gönderen kişi Frank Hükümdarı Charlemagne olmuştur. ${ }^{107}$ Sefaret heyeti, ikisi Katolik, birisi Musevî olmak üzere 3 kişiden oluşmaktadır. ${ }^{108}$ Heyet, beraberindeki hediyelerle Harûn er-Reşîd'den Hristiyan hacıların Kudüs'ü güvenle ziyaret etmeleri için gerekli kolaylığın gösterilmesini istiyordu. ${ }^{109}$ Heyet hüsnü kabul gördü ve hatta Harûn, Kudüs'teki Holy Sepulchre (Kutsal Mezar Kilisesi) kilisenin

100 Thomas B. Irwing, "Kurtuba”, DIA, İstanbul 2002, c. XXVI, s. 452.

101 İbn Havkal, s. 104.

102 Mukaddesî, s. 247.

103 Potyemkin, c. I, s. 77.

104 Potyemkin, c. I, s. 76.

105 Hitti, History, s. 299.

106 J. F. Michaud, Haçlı Seferlerinin İlginç Olayları, haz.: Güray Kırpık, Lotus Yayınevi, Ankara 2011, s. 36.

107 Ali Reşad, Tarih-i Umumî, Şems Matbaası, İstanbul 1342, c. II, s. 329; Hitti, History, s. 298.

108 Ali Reşad, c. II, s. 329. Vaglieri, c. I, s. 128'de heyetin iki kişiden ibaret olduğunu söyler. Muhammed Hudari, c. I, s. 133'de ise Yahudi İshak adında birisinin adını verir. Bu iki rivayet Ali Reşad'1 tamamlar.

109 TTK Cemiyeti, Tarih, İstanbul 1933, c. II, s. 150; F. Omar, "Harûn al-Rashid", EI², c. III, s. 232-234. 
anahtarlarını Charlemagne'ye gönderdi. ${ }^{110}$ Charlemagne da Harûn'a beyaz ve yeşil çuha ile av zağarı hediye etmişti. ${ }^{111}$

Charlemagne de Harûn'un heyetini Aix-La-Chapelle'de kabul etti. ${ }^{112}$ Harûn'un elçileri, Charlemagne'ye o zamanlar Batı'da pek bilinmeyen çok nadide hediyelik eşyalar sunarak, onun Harûn'a karşı hayranlık duymasını sağlamışlardi. ${ }^{113}$

Hediye edilen eşyalar arasındaki bir çalar saat oldukça meşhurdur. ${ }^{114}$ Bu çalar saatten başka, hediyeler arasında küçük bir org, bir fill15 ve bazı nefis kumaşların da ismi geçer. ${ }^{116}$ Bu hediyeler, Frenkler'i şaşkına çevirdi; bu kıymetli şeyler karşısında hayrete düştüler, hatta sihirli sandıkları saati kırmaya kalkıştılarsa da, İmparator tarafından menedildiler. ${ }^{117}$ Gönderildiği iddia edilen filo kadar ilgi gördü ki, kaynaklarda filin ölüm tarihi dahi ballandırılarak anlatıldı. ${ }^{118}$

\section{P. K. Hitti, bu hediyelerden şöyle bahseder:}

“Charlemagne'yi şahsen tanıyan ve bazı yerlerde O'nun kâtibi olarak adı geçen bir Frenk yazarına göre, Batı'nın bu büyük hükümdarının gönderdiği bu heyetler, yurtlarına "İran hükümdarı Harûn'dan " gayet zengin ve kıymetli hediyelerle dönmüşlerdir ki bunlar arasında mamül eşyalar, baharatlı ve kokulu emtia ve bir de fil bulunuyordu. Bu bilgiler resmî devlet arşivi demek olan Annales Royales'e dayandırılmaktadır ki, bunlardan Bağdat'tan gönderilen eşyalar arasında ayrıca tuhaf ve dikkati çeken bir saatin de bulunduğu zikredilmektedir. Fakat Harûn tarafından Charlemagne'ye gönderildiği söylenen borulu org, tarihin diğer pek çok eğlendirici tarafları gibi ancak bir faraziyeden ibarettir. Batı'daki tarih kitaplarında rastlanan bu hikâye anlaşılıyor ki, "clepsydra" kelimesinin yanlış bir tercümesi üzerine inşa edilmiştir ki, bu şey gerçekte zamanı ölçmek üzere imal edilmiş bir su saatiydi ve her halde yukarıda adı geçen saate işaret etmekte idi." 119

110 Hitti, History, s. 299; Potyemkin, c. I, s. 76'da bu anahtarı Kudüs'teki patriğin gönderdiğini belirtir.

111 Michaud, s. 36.

112 C. Brockelmann, İslâm Milletleri ve Devletleri Tarihi, çev.: Neşet Çağatay, Ankara Üniversitesi Basımevi, Ankara 1964, s. 107.

113 Vaglieri, Tarih, c. I, s. 128.

114 Hitti, 298; Muhammed Hudari, Tarih, I/133; G. Labon, Hadâretü'l-Arab, çev.: Adil Zuaytır, Kahire 1948, 215; G. Sarton, Introduction of the History of Science, London 1962, c. I, s. 527.

115 Michaud, s. 36'da hediyeyi fildişi olarak verir. Ayrıca hediyeler arasında bir Meryem buhuru olduğunu ilâve eder.

116 Muhammed Hudari, c. I, s. 133.

117 Muhammed Hudari, c. I, s. 133.

118 V. Potyemkin, c. I, s. 76.

119 Hitti, s. 299. 
Son dönem İslâm Tarihçilerinden Muhammed Hudari, bu münasebetler vasitası ile Charlemagne'nin Harûn'un ilmî potansiyelinden istifade ettiği görüşündedir. Zira Avrupa, bu sıralarda cehalet içerisinde idi. Roma inkıraza uğramıştı. Berber kavimler Avrupa'ya galebe çalmış ve ilim ışığı sönmüştü. Oysa İslâm ülkelerinde durum tam tersi idi. Ona göre ilim Kurtuba ve Bağdat'ta denkti. Charlemagne, Harûn'u taklit ederek kanunlarını islah etmişti. Yine bu dönemde Bağdat'tan Avrupa'ya doktorlar gitmişti. ${ }^{120}$

Bahsettiğimiz bütün teferruat, batılı kaynaklardan etkilenen son dönem bir-kaç ikincil kaynak bir yana bırakılacak olursa, sadece Batılı kaynaklarda anlatılır. ${ }^{121}$ Tüm bu gelişmelerden İslâmî ana kaynaklarda tek kelime ile olsun bahsedilmez. Sadece Endülüslü âlim ve şâir İbn Abdürrabbih (ö.328/940)' in ${ }^{122}$ eserinde geçtiği söylenen yanlış ve tenakuzlarla dolu Hitti' de alıntı bir rivayet vardir:

“İbn Abdürrabbih, "Ikdu'l-Ferîd" adlı eserinde Hindistan kralından gelen ve Harûn'a pek kıymetli hediyeler getiren bir heyetten bahseder. Bu heyet pek tantanalı bir şekilde kabule mazhar olmuşlardı. Bir diğer kaynak, Harûn'un oğlu Me'mun'un özel bir zenginliği olan bir hediyeyi kendi çağdaşı "Romanlar'ın Kralı" ndan, muhtemelen II. Mişel'den aldığını kaydeder." 123

Batılı kaynaklarda karışık ve farklı ifadelerle anlatılan bu hediyeleşmeden İslâmî kaynaklarda tek kelime ile söz edilmemesi, böyle bir karşılıklı ilişkinin olmadığını gündeme getirir. Brockelmann:

“...burada doğrudan doğruya halifenin emri olmaksızın, kendilerini halifenin elçileri olarak tanıtmış olan doğulu tüccarların bahis mevzusu olması da tahmin edilebilir"

diyerek $^{124}$ olayın İslâmî kaynaklarda anlatılmamasına neden bulmaya çalışır.

120 Muhammed Hudari, c. I, s. 133.

121 bk. F. F. Scmidt, Karl der Grosse und Harûn al-Rashid, 1912; Bucker, Harûn al-Rashid and Charles the Great, 1931; E. Joranson, The Allaged Frankish Protoctorate in Palestine, 1927; J. F. Michaud, Haçlı Seferlerinin Illginç Olayları, s. 36; ayrıca bu konuda Iraklı bir bilim adamı da eser yazmiştır: M. Haddurî, es-Silatü'l-Diblomatikiyya beyne'r-Reşid ve Şarlman, Bağdat 1939.

122 bk. Mustafa Muhammed eş-Şek'a, “İbn Abdürrabbih”, DİA, İstanbul 1999, c. XIX, s. 281-283.

123 Hitti, History, s. 299; İbn Abdürrabbih, Kitâbü'l-Ikdi'l-Ferîd, tahk.: Muhammed et-Tancî, Dâru Sâdır, Beyrut ts. c. III, s. 169'da kısaca Hind hümümdarının Hârun er-Reşî́d'e Hindistan'da Kâliyye denilen yerde yapılan kılıçlar, Suriye köpekleri (muhtemelen av köpekleri) ve Hint elbiseleri gönderdiği belirtilir.

124 Brockelmann, s. 107. 
Bir başka Oryantalist Vasilij Viladimiroviç Barthold, "Christianskij Vastok" dergisinde (VI-1912, s. 203-204) yayımlanan "Karl Velikiji Harûn ar-Rasid" adlı araştırmasında, Charlamagne ile Harûn arasındaki münasebetler üzerinde durarak, bu iki hükümdar arasında sanıldığı gibi elçi olmadığını ispat etmeye çalışmıştır. ${ }^{125} \mathrm{Bu}$ konuda müstakil olarak yaklaşık 65 sahifelik bir kitapçık yazma lüzumu hisseden F. W. Bucker, "nihâ̂ bir karara varmak zordur" diyerek verilen bilgiler ışığında bir sonuca gitmeye çalışır. ${ }^{126}$

Ancak batılı kaynaklarda bütün bu teferruatlı bilgilerin nereden çıktığı da insanı düşündürür. Bize göre, batının o dönemde doğudaki zenginliklere olan hayranlığı abartılarak ve hayal güçlerinin de yardımı ile bu hayranlıklarını dile getirmeleri, batıda oldukça yaygın olan "One and Thousand Nights" veya "Elfe Leyl ve'l-Leyl" Bin Bir Gece Masalları' nin da buna yardımcı olması, bu nevi abartılı anlatımları beraberinde getirmiştir. Hediyeler arasında zikredilen borulu org, çalar saat, bir adet fil, çeşitli baharatlar ve kıymetli kumaşlar, zaten Bin Bir Gece Masalları' nin ana öge ve zenginlikleridir. Harûn'un Charlemagne'ye gönderdiği iddia edilen bu hediyelerde de bu özellikleri açıkça görmek mümkündür. Batı dünyasında Arap edebiyatının bilinen en iyi eseri olan Bin Bir Gece Masalları' nın ${ }^{127}$ merkezinde Harûn er-Reşîd'in bulunduğu da ${ }^{128}$ unutulmaması gereken önemli bir husustur. Diğer yandan Bin Bir Gece Masalları meraklı kitlelerin aklından geçen gizli isteklerin, tabuların ve korkuların bir kesintisini sunmakta oldukça mahirdi. ${ }^{129}$

Bu hediyeler arasında ismi geçen şeyler, yukarıda bahsettiğimiz gibi saat, fil, borulu org, baharatlar ve nadide kumaşlar olarak karşımıza çıkar. Konuyu daha iyi anlayabilmek ve sağlıklı bir neticeye varmak için, bu hediyelerin Doğu'daki ve Harûn'a kadar İslâm dünyasındaki karşılıklarına bakmak yerinde olacaktır.

125 Semavi Eyice, “Barthold, Vasilij Viladimiroviç”, DİA, İstanbul 1992, c. V, s. 86.

126 F. W. Bucker, Harûn Rashid and Charles the Greath, Cambridge 1931, s. 3.

127 Carole Hillenbrand, Müslümanların Gözünden Haçlı Seferleri, çev.: Nurettin Elhüseyni, Alfa yayınları, 1. Baskı, İstanbul 2015, s. 275.

128 Veli Ulutürk, "Binbir Gece" DİA, İstanbul 1992, c. VI, s. 180.

129 R. Kruk, "The Bold and the Beautiful. Women and Fitna in the Sirat Dhat al-Himma: The Story of Nura", Women in the Medieval İslamic World: Power, Patronage, Piety, edit.: G. Hambly, New York 1998, s. 2; Hillenbrand, s. 275. 


\section{Değerlendirme}

Devlet başkanları ve ülkeler arası hediyeleşmek geleneğinin İslâm'daki karşılı̆̆ını ortaya çıkarmakta yarar görüyoruz: Hz. Muhammed'in hediyeleşmeyi teşvik eden hadisleri' ${ }^{130}$ yanında, sadakayı geri çevirip, hediyeyi kabul etmesi ve buna yine bir hediye ile karşılık vermesi ${ }^{131}$ gibi hususlar İslâm kültüründe hediye ve hediyeleşmeye büyük bir önem atfetmiştir. Tarihin belirli devirlerinde devlet başkanlarının birbirlerine gönderdikleri hediyeler de önemli fonksiyonlar icra etmiştir. Bunlar arasında hatıralarda en çok kalan olay ise hiç şüphesiz, Hz. Muhammed ile Habeşistan Necaşîsi Ashame arasındaki hediyeleşmedir. H. 7. yılın başında, (Mayıs 628) Hz. Muhammed, Necâşı̂’ye ashabdan Amr b. Ümeyye ed-Damrî'yi ${ }^{132}$ iki mektup ve bazı hediyelerle göndermişti. Mektuplardan birinde İslâm'a davet mektubu, diğerinde ülkesindeki muhacirler arasında bulunan Ebû Süfyân'ın kızı Ümmü Habibe ile nikâhının kıyılması ${ }^{133}$ ve onunla birlikte muhacirlerin Medine'ye gönderilmesi talebi vardı. Necaşî, daveti kabul ederek İslâm'a girmiş, Hz. Peygamber'e de bir çift mest, Mısır işi bir elbise, sarık, iç giysisi, üç tane kısa mızrak, bir yüzük ve bir katır yollamıştır. ${ }^{134}$

Müslümanlar ile Batılılar arasındaki hediyeleşmeye vereceğimiz en iyi örnek ise, yakın tarihin bir hatırasını yaşatması bakımından oldukça ilginç olarak hafızalarda yer edinen Alman İmparatoru II. Wilhelm tarafından Sultan II. Abdülhamit'e hediye olarak gönderilen çeşmedir. "Alman Çeşmesi" adıyla Sultan Ahmet Meydanı'nda bulunan bu çeşme, II. Wilhelm'in Osmanlı Sultanı II. Abdülhamit'i ikinci ziyaretinin hatırası olarak 19 Kasım 1898'de Bizans'ın vaktiyle hipodromu olan eski Atmeydanı'nda inşa ettirilmiştir. Bütün parçaları Almanya'da hazırlatılan çeşme, İstanbul'a getirilerek burada

130 bk. el-Muvatta', "Hüsnü'l-Huluk”, 16; Müsned, II, 405; Tirmizî, "Velâ", 6.

131 bk. Buhârî, "Hibe”, 7; Şevkânî, V, 377-393; Abdülhay el-Kettânî, I, 273, 276; II, 66, 207-209, 310; III, 164.

132 Amr, eskiden beri elçilik hizmetleriyle tanınmıştı ve daha önce de, Hendek savaşından sonra Mekke'de çıkan kuraklıkta fakirlere dağıtılmak üzere Ebû Süfyân'a beşyüz dinar götürme görevini üstlenmişti. bk. İbn Sa'd, et-Tabakât, c. II, s. 93-94; Mustafa Fayda, “Amr b. Ümeyye", DİA, İstanbul 1991, c. III, s. 94-95.

133 Necaşî bu nikâhı vekil tayin ettiği Hâlid b. Saîd vasıtası ile kıydırmış, Rasûlullah adına Ümmü Habibe'ye 400 dinar mehirle bir gerdanlık vermiştir. bk. Zehebî, Siyeru A'lâmi'nNübelâ, neş.: Şuayb el-Arnavud v. dğr., Beyrut 1401-1405/1981-1985, c. II, s. 218-23; Aynur Uraler, "Ümmü Habibe”, DİA, İstanbul 2012, c. XLII, s. 318.

134 Belâzurî, Ensâbü'l-Eşrâf, neş.: Süheyl Zekkâr-Riyâz Ziriklî, Beyrut 1417/1996, c. I, s. 73; Levent Öztürk, "Necâşî Ashame", DİA, İstanbul 2006, c. XXXII, s. 476. 
birleştirilmiş, hattat Mehmed İzzeddin Efendi de sülüs yazı ile kubbeyi taşıyan kemerlerin iç tarafına ziyaret yılını gösteren bir yazı yazmıştır. ${ }^{135}$

Ülkeler ve sultanlar arası hediyeleşmenin ilginç ve sıra dışı örnekleri ile devam edecek olursak, şunları ilâve edebiliriz: Hint hükümdarı Kayd tarafından Büyük İskender'e hediye edilen dört önemli şeyden biri olan ayna da oldukça ilgi çekicidir. "Âyine-i İskender" olarak bilinen bu gizemli aynanın yalancıların görüntülerini yansıtmadığı, İskender'in de bir kimsenin yalan söyleyip söylemediğini böylece anladığı efsane olarak halâ kulaktan kulağa anlatılır. ${ }^{136}$ Bir dostluk nişanesi olarak Kırgızlar Cengiz Han'a beyaz bir doğan göndermişler, Tomanbay ${ }^{137} \mathrm{da}$, tımar sahibi olabilmek umuduyla Gazan Han (1295-1304)'a $\mathrm{a}^{138}$ eğitilmiş bir şahin hediye etmişti. ${ }^{139}$ Harûn tarafından Charlemagne'ye takdim edildiği iddia edilen hediyelere tek tek göz atacak olursak yukarıdaki verildiği iddia edilen hayalî hediyelerle (Âyine-i İskender gibi) örtüşen tarafları bulup, daha sağlıklı bir değerlendirme yapabiliriz.

\section{Saat}

Hediyeler arasındaki en dikkat çeken saat ile başlayacak olursak, tarihsel süreç içerisinde karşımıza ilginç detaylar çıkar. Saatle ilgili olarak ilk elde ettiğimiz bilgi, meşhur cebir ilminin kurucusu kabul edilen astronom, matematikçi ve coğrafyacı Muhammed b. Musâ el-Harezmî (ö. 232/847) ${ }^{140}$ ye atfedilir. $\mathrm{O}$, namaz vakitlerini belirlemeye yarayan pergel gibi basit bir aleti tarif etmektedir. İşleyişi oldukça basittir. ${ }^{141}$ Yine bir başka örnek olarak Yemen' deki Resûlîler Hanedanı'nın üçüncü sultanı el-Melikü'l-Eşref Ömer b. Yusuf (694-696/1295-1296)'un eserinde ${ }^{142}$ verilen Kahire'nin enlem derecesi için imal ettiği güneş saati çizimini verebiliriz. ${ }^{143}$ İslâm Bilim Tarihi'nde ilkler

135 C. Gurlitt, Die Baukunst Konstantinopels, Berlin 1909-12, c. I, s. 90; İ. Hakkı Konyalı, “Alman Çeşmesi", Tarih Hazinesi, I/8, İstanbul 1951, s. 383-87.

136 İskender Pala, "Âyine-i İskender", DİA, İstanbul 1991, c. IV, s. 252.

137 Yavuz Sultan Selim ile mücadele eden son Memlük Sultanı Tomanbay ile karıştırmamak gerekir. Sultan Tomanbay'ın vefatının 1517 olduğuna bakacak olursak, arada yaklaşık 2 asır olduğunu görürüz. bk. P. M. Holt, "Tuman Bay", $E I^{2}$., c. X, s. 621-22. Buradaki Tomanbay da Gazan Han'ın Memlükler ile olan mücadelesi hatırlanırsa, yine bir Memlük komutan olmalıdir.

138 İslâmiyet'in İlhanlılar'ın resmî dini olmasını sağlayan İlhanlı hükümdarıdır. bk. Abdülkadir Yuvalı, "Gâzân Han", DİA, 1996, İstanbul 1996, c. XIII, s. 429-431.

139 Abdülkerim Özaydın, “Av”, DIA, İstanbul 1991, c. IV, s. 102-103.

140 bk. J. Vernet, “al-Khwarazmi”, EI', c. IV, s. 1070-1071.

141 Fuat Sezgin, c. III, s. 85.

142 Ömer b. Yusuf, “Muinu't-Tullâb alâ Ameli'l-Usturlab”. Sezgin, c. III, s. 87.

143 Sezgin, c. III, s. 87. 
arasında verilen bu bilgiler ve mucitlerinin vefat tarihleri Harûn er-Reşid'den sonradır. Hitti'nin yukarıda bahsettiği su saati ise, Ortaçağ İslâm dünyasında kullanıldığı gerçeğinden hareketle kabul edilebilir gibi görünmesine rağmen, Avrupalılar'ı hayret içinde bırakacak özelliği yoktur. Zira su saati çok önceleri Antik Mısır'da ortaya çıkmıştı ${ }^{144}$ ve herkesçe malum olması gerekirdi.

\section{Fil}

Gönderildiği söylenen fil de en az saat kadar ilgi çekici bulunmuştur. İslâm âleminde fil pek bilinmeyen bir hayvandır. İlk bilgiler Fil Vak'ası'ndaki Ebrehe'nin meşhur fili Mahmûd'dur. ${ }^{145}$ Tarihte İskender ile III. Daryüs arasında yapılan savaştan ve Kartacalı Hannibal'den hatırladığımız filler, tarihin başka aralıklarında da karşımıza çıkmıştır. ${ }^{146}$ İslâm Tarihinde ise, ilk kez Müslümanlar Kadisiye Savaşı' nda $(15 / 536)^{147}$ fillerle karşılaşmışlardır. Bu savaşta Sasânî ordusunda 30 kadar filin bulunduğu, fakat ilk andaki korkularını atlatan Müslümanların mahfe kolonlarını keserek üzerindekileri düşürmeleri, sonra da fillerin gözlerini hançerleyerek onları etkisiz hale getirdikleri kaynaklarda zikredilmektedir. ${ }^{148}$ Daha sonraki bildiğimiz fillerle ilgili ikinci bilgi Gazneliler Dönemi (963-1186)'ne aittir. Gazneliler'in kurucusu Sebük Tekin'in oğlu Sultan Mahmut Gaznevî (ö. 421/1030) ${ }^{149}$, on yedi Hint seferinin her birinde yüzlerce fil ganimet almış ${ }^{150}$ ve Gazne yakınındaki Şâhbâr düzlüğünde yaptırdığı büyük geçit resmine tam teçhizatlı 1300 fil katılmıştır. ${ }^{151}$ Batılılar için fil objesi o kadar değerli olmalı ki bu olaydan yaklaşık 450 yıl sonra Suriye Haşhaşîleri'nin lideri "Dağın Yaşlı Adamı" Tâceddin Ebü'l-Feth"152, Haçlı Seferleri için Ortadoğu'ya gelen Kral Louis'e iyi münasebetlerinin bir nişanesi olarak kristal bir fil maketi hediye etmişti. ${ }^{153}$

144 Atilla Bir- Mustafa Kaçar, "Saat", DIA, İstanbul 2008, c. XXXV, s. 323.

145 bk. Taberî, Câmiu'l-Beyân an Te'vîli Âyi'l-Kur'ân, Beyrut 1986-87, c. XXX, s. 296-304; Fîl Sûresi, 105/1-5.

146 Tahsin Yazıc1, “Fil”, DIA, İstanbul 1996, c. XIII, s. 67-68.

147 Müslümanlara Kuzey Irak ve İran'ın kapılarını açan Sasânîler'le yapılan meydan savaşıdır. Ahmed Âdil Kemâl, el-Kadisiyye, Beyrut 1989.

148 Taberî, Tarih, c. III, s. 359 vd.

149 bk. M. Hanefi Palabıyık, Valilikten Imparatorluğa Gazneli Devlet ve Saray Teşkilâtı, Araştırma Yayınları, Ankara 2002.

150 Tahsin Yazıc1, “Fil”, DIA, İstanbul 1996, c. XIII, s. 67-68.

151 Gerdizî, Zeynü'l-Ahbâr, neş.: Mirza M. Kazvînî, Tahran 1315, s. 63.

152 Farhad Daftary, İsmaililer, Tarihleri ve Öğretileri, çev.: Ahmet Fethi, Melisa Matbaacılık, 1. Baskı, İstanbul 2017, s. 591.

153 Lamb, s. 431. 
Bu bilgilerde de, fillerin kaynağı İran ve Hint kökenlidir. Bildiğimiz kadarıyla Bağdat'ta fil kullanımı ile askerî ve kültürel anlamda bir veri mevcut değildir. Hal böyle olunca olmayan iri cüsseli bir filin Bağdat'tan veya Kayrevan'dan ${ }^{154}$ Frenk hükümdarına, başkenti Aix'e ulaşması pek çok müşkülatla ve zorluklarla dolu bir konudur ki, gerçekleşmesi pek de mümkün gibi görünmüyor. Hannibal'in, fillerini Roma'ya karşı Avrupa'ya sevk etmesi ise, İspanya üzerinden olduğu için ${ }^{155}$ mümkün olabilmiştir.

\section{Borulu Org}

Borulu org ise, "Bin Bir Gece Masalları"'nın sihirli ve parıltılı havasıyla örtüşen bir başka tarihî ve kültürel açmazdır. Doğu müziğinin enstrümanları ile hiç de alâkası olmayan, özellikle kilise müziği ile özdeşleşen ve Batıyı temsil eden bir sazın hem de Bağdat'tan, Aix'e gitmesi hiç de akılcı değildir. Doğunun ilk akla gelen çalgı aleti ut benzeri enstrümanın aidiyetinin Eski Mısır'da 1929. Sülaleler dönemine (M.Ö. 1320-1085) kadar gittiğini buradan Asya'nın diğer bölgelerine yayıldı̆̆ını biliyoruz. ${ }^{156}$ Harûn ile aynı çağda yaşayan Zelzel (ö.174/790), ut enstrümanına getirdiği yenilikle bilinir. ${ }^{157}$ Şark musikisinin bir başka yaygın çalgı aleti de kanundur. Filozof Farâbî'nin icat ettiğine inanılan bu enstrüman, aynı zamanda Endülüs çalgılarının en itibarlısı olarak bilinir. ${ }^{158}$ Doğunun arabesk müziği içinde bulunma ihtimali olmaması yanında, temin edilme güçlüğünün çok olduğu bir çalgı aletinin Büyük Karl'a gönderilme ihtimali zayıf görünüyor. Hitti, bunu bir faraziye olarak görür. ${ }^{159}$

\section{Baharat ve Kumaşlar}

Ticarî meta özelliği taşıyan diğer iki hediye ise, baharat ve kumaş ticaretinin merkezinin doğu olması açısından diğerlerinden daha mantıklı göründüğü de bir gerçektir. İpekyolu ve bağlantılarıyla Ortadoğu'ya çok değerli elbiselik kumaşların geldiği bilinen bir husustur. ${ }^{160}$ Hatta Harûn'un kız kardeşinin

154 İbrahim $\mathrm{b}$. Ağleb, Ifrîkıyye valisi olarak atanması halinde halifeden hiçbir şey istemeyeceği gibi, Bağdat'a da yıllık 40.000 dinar gönderme karşıllı̆ında burada, babadan oğula intikal eden bir özerk devlet kurmuş ve Kayrevan'ı kendisine üs edinmişti. O'nun vali olduktan 1 yil sonra 185/801'de Charlemagne' nin elçilerini kabul ettiği söylenir. bk. Hasan İbrahim Hasan, Tarihu'l-İslâm es-Siyasî ve'd-Dinî ve's-Sekâfî ve'l-İctimâ̂î, Beyrut 1991, c. II, s. 124. bk. Büyük Kültür Ansiklopedisi, Başkent Yayınları, Ankara ts., c. V, s. 2075.

156 Habib Hassan Touma, La Musique Arabe, Paris 1996, s. 91-95.

157 Fikret Karakaya, “Ud”, DİA, İstanbul 2012, c. XLII, s. 39-40.

158 Abdülkadir-i Merâgî, Câmiu'l-Elhân, neş.: Takî Bîniş, Tahran 1987, s. 203.

159 Hitti, c. II, s. 459.

160 Nebi Bozkurt, “Kiyafet”, DİA, İstanbul 2002, c. XXV, s. 508-510. 
başörtüsünün üzerine taktığı mücevherler Batılı oryantalistlerin ilgisini çekmiştir. ${ }^{161}$ Hitti, Arap tüccarların Avrupa'ya "mamul eşya, kıymetli işlenmiş taşlar, madenî aynalar, inci-boncuklar ve baharat" gibi ticarî eşyaları ihraç edip sattıklarını anlatır. ${ }^{162}$ Doğu'nun kıymetli eşyalarına düşkün Batılı yazarlar bu gerçekten hareketle gönderildiği iddia edilen hediyelerin arasına bunları da dâhil etmişlerdir. Yahut da baharat ve değerli kumaşlar, Arap tüccarlar Charlemagne'ye bir şekilde bunları ticarî imtiyaz için hediye etmiş yahut da aracılar vasıtası ile satmış da olabilirler.

Yukarıda verilen bilgiler ışı̆̆ında, genel bir değerlendirme yapacak olursak, elçilerin karşılıklı olarak gidip-gelmeleri, daha önceden de ele aldığımız ölçüde mümkün görünüyor. Fakat Charlemagne'nin Harûn'a gönderdiği herhangi bir hediyeden söz edilmezken, her iki kabulde de Harûn'un hediyelerinin ön plana çıkarılması ve bu hediyelerin özellikleri kafaları karıştırmakta, sonradan uydurulan veya başka münasebetlerle karıştırılan olaylar olarak karşımıza çıkmaktadır.

Bütün bu belirsizlik içerisinde, tarihimizde kesin olarak bildiğimiz bir başka Müslüman-Frenk dostluk ilişkisi, bu olaydan yedi asır sonra Batılıların "Muhteşem Süleyman" diye andıklar1 ${ }^{163}$ Kanunî Sultan Süleyman ile Fransa Kralı I. François arasında tekrarlamıştır. ${ }^{164}$ Avrupa'daki iktidar mücadelesi kızıştı̆̆ında, Fransa Kralı I. François 1525'de V. Karl'a (Charles Quint) yenilip esir düşmüş, annesi de oğlunun kurtarılması için Kanunî’den yardım talep etmişti. Macar krallığını ortadan kaldırıp, Habsburglar'la karşı karşıya kalmak için bunu bir fırsat bilen I. Süleyman, İstanbul'a gelen Fransa elçisi Johann Frangepan'a, Fransa kralına yardım için Macar seferine çıkacağını bildirmişti. Hatta Kanunî cevabî mektubunda Fransa Kralını teselli ediyor ve yardım için hareket edeceği taahhüdünde bulunuyordu. ${ }^{165} 1536$ 'da Fransa'ya verilen ahidnâme ile Osmanlı sınırları içinde dinî, siyasî ve hukukî sahalarda önemli imtiyazlar tanınmış, böylece Fransız tüccar, misyoner ve diplomatları imparatorluğun en önemli merkezlerine yerleşerek Müslümanları tanıma firsatı bulmuşlard1. ${ }^{166}$

161 Hitti, c. II, s. 534.

162 Hitti, c. II, s. 469.

163 bk. Renzo Sertoli Salis, "Muhteşem Süleyman”, çev.: Şerafettin Turan, AÜ Dil ve Tarih Coğrafya Fakültesi, Ankara 1963.

164 Riza Kurtulmuş, “Avrupa”, DIA, İstanbul 1991, c. IV, s. 152-153.

165 Feridun Emecen, "Süleyman I", DIA, İstanbul 2010, c. XXXVIII, s. 64-65. Ayrica bk. H. Lamb, Suleiman the Magnificent: Sultan of the East, New York 1951.

166 Faruk Bilici, “Fransa”, DIA, İstanbul 1996, c. XIII, s. 181. 


\section{Sonuç}

VIII. yüzyılın sonları ve IX. yüzyılın hemen başlarında Doğu'nun yükselen medeniyeti hiç şüphesiz Abbasî Devleti ve onun Halifesi Harûn er-Reşîd'dir. O dönemin ikinci büyük gücü olan Bizans'1 itaat altına alması yanında, kurduğu medeniyet, halkının yüksek refah seviyesi, dönemindeki ilmî gelişmeler, sanat ve edebiyattaki zirve, yeni fetihler ve müesseseler ile sadece Doğu'da değil, Batı'da da ilgi ile izlenmektedir.

Batı' da ise Charlemagne önemli gelişmeler kaydetmiş, Avrupa'yı itaat altına alarak Bizans ile komşu olmuştur. Kendisini Batı'nın tek hâkimi olarak görmesi yanında, Doğu' daki Hristiyanların da hamisi olarak tanımlamaktadır. Bizans ile güç mücadelesi içine girdiği bu dönemde, İmparator Nikeforos'a karşı parlak zaferler kazanan Harûn er-Reşîd'e de bir yakınlık duymaktadır. er-Reşîd de kendisinden çok uzak bir coğrafyada kurulan Endülüs Emevîleri'ne karşı, Charlemagne'yi bir müttefik olarak görmektedir. BağdatAix arasında bir yakınlaşma olmuş, elçilik heyetleri karşılıklı olarak gelip gitmeye başlamıştır. Karşılıklı gelip giden elçilerin üzerinde durdukları temel konu Kudüs'teki Hristiyanlar'ın sorunlarının giderilmesi ve diğer netlik kazanmayan konulardır.

İki kudretli hükümdar arasında bir de karşılıklı hediye alış verişi olmuştur ki, bu tarihçilerin ve meraklıların ilgisini daha çok çekmiş, konu ile ilgili çok şey yazılmış ve söylenmiştir. Avrupa'da Doğu'nun zenginliklerinin ve yaşadığı ileri düzeydeki yaşamın parıltılı anlatımı olan "Bin Bir Gece Masalları"nın da katkısı ile abartılı ifadeler ve detaylarla konu gerçeklerden uzaklaşmıştır. Herhangi bir hediye alış verişinden temel İslâmî kaynaklar tek kelime ile bahsetmezken, Batı'da hediyelerin vasıfları o dönemin zengin Doğu algısıyla abartılarak masalımsı detaylarla anlatılmış ve yaygınlaşmıştır. Hediye edildiği iddia edilen nesneler de onların zengin doğu algısının bir sonucudur. Sonuç olarak, iki hükümdar arasında elçilerin gelip gitmiş olabileceği, ama böyle bir hediye alış verişinin olmadığı, tarihî olayların ve efsanelerin ışı̆̆ında sonradan uydurulmuş olabileceği ortaya çıkmıştır.

\section{Kaynakça}

Abdülganî, Abdurrahman M., el-Hudûdü'l-Bizantiyye el-İslâmiyye ve Tanzîmâtüha's Sagriyye (40-339/660-950), Küveyt 1410/1990.

Ahmed Âdil Kemâl, el-Kadisiyye, Beyrut 1989.

Ahmed Emin, Duha'l-İslâm, Beyrut 1933-36.

Ali Reşad, Tarih-i Umumî, Şems Matbaası, İstanbul 1342.

al-Kholy, Amin, The Function of Music in Islamic Culture, Cairo 1984.

Hitit Üniversitesi İlahiyat Fakültesi Dergisi, 2017/2, c. 16, sayı: 32 
Asbridge, Thomas, Haçlı Seferleri, çev.: Ekin Duru, Say Yayınları, 1. Baskı, İstanbul 2014.

Avc1, Casim, "Kudüs", DIA; İstanbul 2002, c. XXVI, s. 327-329. "Suğur", DİA; İstanbul 2019, c. XXXVII, s. 473-474.

Barthold, W., Köprülü F., İslâm Medeniyeti Tarihi, Akçă̆ Yayınları, Ankara 1984.

Belâzürî, Futuhu'l-Buldan, çev.: Mustafa Fayda, Siyer Yayınları, 1. Baskı, Ankara 1986.

Bilge, Mustafa L., “Süveyş", DİA; İstanbul 2010, c. XXXVIII, s. 186-187.

Bilici, Faruk, “Fransa”, DIA İ̀stanbul 1996, c. XIII, s. 187-190.

Bir, Atilla - Kaçar Mustafa, "Saat”, DİA; İstanbul 2008, c. XXXV, s. 322-325.

Bozkurt, Nahide, "Hârûnürreşîd", DİA; İstanbul 1997, c. XVI, s. 258-261.

"Herseme b. A'yen", DIA, İstanbul 1998, c. XVII, s. 239.

Bozkurt, Nebi, “Kiyafet", DIA, İstanbul 2002, c. XXV, 508-510.

Brockelmann, c., İslâm Milletleri ve Devletleri Tarihi, çev.: Neşet Çağatay, Ankara Üniversitesi Basımevi, Ankara 1964.

Bucker, F. W., Harûn Rashid and Charles the Greath, Cambridge 1931.

Candarlığlu, Gülçin, “Çin”, DİA, İstanbul 1993, c. VIII, s. 322-23.

Continuatus, Theophanes, Chronographia, Corpus Scriptorum Historiae Byzantinae, Bonn 1838.

Demirkent, Işın, “Bizans”, DİA, İstanbul 1992, c. VI, s. 235.

“İstanbul”, DIA, İstanbul 2001, c. XXIII, s. 205-212.

Ebû Yusuf, Kitâbü'l-Harâc, neş.: Muhibbüddin el-Hatîb, Kahire 1382.

ed-Dûrî, Abdülaziz, "Bağdat”, DIA, İstanbul 1991, c. IV, s. 425-433.

el-Alûsî, Mahmud Şükrî, Tarîhu Mesâcidi Bağdâd ve Asâruhâ, Bağdat 1346.

el-Fakî, Usamuddin Abdurrauf, ed-Devletü'l-Abbasiyye, Kahire 1987.

el-Hudari, Muhammed, Tarihu'l-Ümemi'l-İslâmiyye, (ed-Devletü'l-Abbasiyye), Misır 1970.

el-Kıftî, Ali b. Yûsuf, Kitâbu İhbâru'l-Ulemâ bi Ahbâri'l-Hukemâ, Kahire 1326.

Emecen, Feridun, “Süleyman I", DIA, İstanbul 2010, c. XXXVIII, s. 64.

eş-Şek'a, Mustafa Muhammed, “İbn Abdürrabbih”, DİA, İstanbul 1999, c. XIX, s. 281-283.

et-Taberî, Tarihu'r-Rusül ve'l-Mülûk, tahk.: Muhammed Ebu'l-Fadl İbrahim, Kahire 1968-69.

Eyice, Semavi, “Barthold, Vasilij Viladimiroviç”, DİA, İstanbul 1992, c. V, s. 86.

ez-Ziriklî, Hayreddin, Kamusu'l-A'lâm, (Kamus-u Terâcim), neş.: Züheyr Fethullah, Beyrut 1980.

Fayda, Mustafa, “Amr b. Ümeyye”, DIA, İstanbul 1991, c. III, s. 94-95.

Fück, J. W., “Ishak b. Ibrahim al-Mawsiliı”, $E I^{2}$, c. IV, s. 110-111.

Gerdizî, Zeynü’l-Ahbâr, neş.: Mirza M. Kazvînî, Tahran 1315.

Gurlitt, C., Die Baukunst Konstantinopels, Berlin 1909-12.

Haddurî, M., es-Silatü'l-Diblomatikiyya beyne'r-Reşid ve Şarlman, Bağdat 1939.

Hasan İbrahim Hasan, Tarihu'l-İslâm es-Siyasî ve'd-Dinî ve's-Sekâfi ve'l-İctimâ̂, Beyrut 1991.

Hızır Ahmed Atâullah, Beytü'l-Hikme fì Asri'l-Abbasiyyîn, Kahire ts. 
Hillenbrand Carole, Müslümanların Gözünden Haçl Seferleri, çev.: Nurettin Elhüseyni, Alfa Yayınları, 1. Baskı, İstanbul 2015.

Hitti P. K., History of the Arabs, New York 1968.

Capital Cities of Arab Islam, Minneapolis 1973.

, Siyasî ve Kültürel İslâm Tarihi, çev.: Salih Tŭğ, Boğaziçi Yayınları, İstanbul 1995.

Holt, P. M., “Tuman Bay", EI², c. X, s. 621-622.

Honigmann, E., Bizans Devleti'nin Doğu Sınırı, çev.: Fikret Işıltan, IÜ Edebiyat Fakültesi Yayınları, İstanbul 1970.

Irwing, Thomas B., "Kurtuba”, DİA, İstanbul 2002, c. XXVI, s. 452.

İbn Battûta, Muhammed b. Abdullah, Tuhfetü'n-Nüzzâr fí Garâibi'l-Emsâr ve Acâibi'l- Esfâr, neş.: Ali el Muntasır, Beyrut 1975.

İbn Cübeyr, Endülüs'ten Kutsal Topraklara, çev.: İsmail Güler, Selenge Yayınları, İstanbul 2003.

İbn Havkal, 10. Asırda İslâm Coğrafyası, çev.: Ramazan Şeşen, Yeditepe Yayınları, İstanbul 2014.

İbn Hurdazbih, el-Mesâlik ve'l-Memâlik, neş.: M. J. De Goeje, Leiden 1967.

İbn Kesir, el-Bidaye ve'n-Nihaye, Beyrut 1966.

İbn'ul-Esir, el-Kâmil fi't-Tarih, Misır, 1301.

Joranson, E., The Allaged Frankish Protoctorate in Palestine, yy. 1927.

Karakaya, Fikret, “Kanun”, DIA, İstanbul 2001, c. XXIV, s. 327-28.

“Ud", DİA, İstanbul 2012, c. LXII, s. 39-40.

Karpat, Kemal H., "Balkanlar”, DIA, İstanbul 1992, c. V, s. 28.

Kaya, Mahmut, "Beytülhikme”, DİA, İstanbul 1992, c. VI, s. 89.

Konyalı, İ. Hakkı, "Alman Çeşmesi”, Tarih Hazinesi, I/ 8, İstanbul 1951.

Kurtulmuş, Rıza, “Avrupa”, DIA, İstanbul 1991, c. IV, s. 152-153.

Kruk, R., "The Bold and the Beautiful. Women and Fitna in the Sirat Dhat al-Himma: The Story of Nura", Women in the Medieval İslamic World: Power, Patronage, Piety, edit. G. Hambly, New York 1998.

Labon, G., Hadâretü'l-Arab, çev.: Adil Zuaytır, Kahire 1948.

Lamb, Harold, Suleiman the Magnificent: Sultan of the East, New York 1951.

Selahaddin Eyyubi ve Haçlılar, çev.: Sinem Ceviz, İlgi Kültür Sanat Yayınları, 1. Bask1, İstanbul 2017.

Le Strange, G., Baghdad During the Abbasid Caliphate, Oxford 1924.

Littmann, E., "Alf layla wa layla", EI², c. I, s. 358-364.

Michaud,. F. J, Haçlı Seferlerinin İlginç Olayları, haz.: Güray Kırpık, Lotus Yayınevi, Ankara 2011.

Mukaddesî, Ahsenü't-Tekasim, çev.: D. Ahsen Batur, Selenge Yayınları, İstanbul 2015.

Omar F., "Harûn al-Rashid", EI²; c. III, s. 232-234.

Ostrogorsky, Georg, Bizans Devleti Tarihi, çev.: Fikret Işıltan, Türk Tarih Kurumu Yayınları, Ankara 1981.

Öğüt, Salim, “Ebû Yusuf”, DİA, İstanbul 1994, c. X, s. 261-264.

Özaydın, Abdülkerim, “Av”, DİA, İstanbul 1991, c. IV, s. 102-103.

Özcan, Azmi, “Fransa”, DIA, İstanbul 1996, c. XIII, s. 178. 
Özdemir, Mehmet, “Endülüs”, DİA, İstanbul 1992, c. XI, s. 213.

, “Hakem I”, DIA, İstanbul 1997, c. XV, s. 173.

Öztürk, Levent, “Necâşî Ashame”, DİA, İstanbul 2006, c. XXXII, s. 476.

Pala, İskender, “Âyine-i İskender”, DİA, İstanbul 1991, c. IV, s. 252.

Palabıyık, Hanefi, Valilikten Imparatorluğa Gazneli Devlet ve Saray Teşkilâtı, Araştırma Yayınları, Ankara 2002.

"Müslümanlarda Kitap Kültürü ve Kütüphaneler", İslâm Kurumları Tarihi, edit.: Eyüp Baş, Grafiker Yayınları, 1. Baskı, Ankara 2013.

Potyemkin, Vladimir ve diğerleri, Uluslararası İlişkiler Tarihi, çev.: Atilla Tokatlı, Evrensel Basım Yayın, İstanbul 2009.

Salis, Renzo Sertoli, Muhteşem Süleyman, çev.: Şerafettin Turan, AÜ Dil ve Tarih Coğrafya Fakültesi Yayınları, Ankara 1963.

Sarton, G., Introduction of the History of Science, London 1962.

Scmidt, F. F., Karl der Grosse und Harûn al-Rashid, yy. 1912.

Sezgin, Fuat, İslâm'da Bilim ve Teknik, çev.: Abdurrahman Aliy, Türkiye Bilimler Akademisi, Ankara 2007.

Sırma, İ. Süreyya, Abbasiler Dönemi, Beyan Yayınları, İstanbul 1990.

Terzi, Mustafa Zeki, “Emeviler ve Abbasiler Zamanında Malatya Hudut Garnizonu”, 19 Mayıs ÜiF Dergisi, Samsun 1989, sayı: 3.

Terzioğlu, Arslan, "Bîmâristan", DİA, İstanbul 1992, c. VI, s. 164.

Touma, Habib Hassan, La Musique Arabe, Paris 1996.

TTK Cemiyeti, Tarih, İstanbul 1933.

Tukin, Cemal, “Girit”, DIA, İstanbul 1996, c. XIV, s. 85.

Ulutürk, Veli, “Binbir Gece” DİA, İstanbul 1992, c. VI, s. 180.

Uraler, Aynur, “Ümmü Habibe”, DİA; İstanbul 2013, c. LXII, s. 318.

Uslu, Recep, “Cündişâpûr”, DİA, İstanbul 1993, c. VIII, s. 117.

Vaglieri, L. V., “Abbasî Hilâfeti”, İslâm Tarihi Kültür ve Medeniyeti, çev.: H. Aktaş, İstanbul 1988.

Vernet, J., “al-Khwarazmi”, EI², c. IV, s. 1070-1071.

Wasserstein, J., The Caliphate in the West, Oxford 1993.

Yazıc1, Tahsin, "Fil”, DİA, İstanbul 1996, c. XIII, s. 67-68.

Yıldız, H. Dursun, “Avâsım”, DİA, İstanbul 1991, c. IV, s. 111.

Yuvalı, Abdülkadir, “Gâzân Han", DİA, İstanbul 1996, c. XIII, s. 429-431.

Zettersteen, K. V., "Harûnurreşid”, İA, İstanbul 1977, c. V/1, s. 304-305. Zeydan, Corci, İslâm Medeniyeti Tarihi, çev.: M. Çelik, İletişim Yayınları, İstanbul 1976. 